\title{
POISONING OF DOMESTIC CARNIVORES BY BANNED PESTICIDES IN SOUTH BAČKA DISTRICT
}

\author{
Biljana Đurđevićc ${ }^{*}$, Milena Samojlović ${ }^{1}$, Brankica Kartalović ${ }^{1}$, \\ Radomir Ratajac ${ }^{1}$, Miloš Pelić ${ }^{1}$, Marko Pajić1 ${ }^{1}$, Vladimir Polaček ${ }^{1}$ \\ ${ }^{1}$ Scientific Veterinary Institute "Novi Sad", Novi Sad, Serbia
}

\section{Abstract}

Cases of deliberate, illegal animal poisoning are widely documented in the literature. Recently, there has been an increase in number of cases of poisoning of domestic and wild animals with highly toxic pesticides in the Republic of Serbia. During the two-year period (2016-2017), in total 40 autopsies of dogs and 2 cats from the territory of the South Bačka District were performed at the Department of Pathology at Scientific Veterinary Institute "Novi Sad" to determine the cause of death. Reasonable suspicion of poisoning in 13 dogs and 2 cats was made based on anamnestic data. The expertises were performed on request of the Republic veterinary inspector in 5 cases, and on the request of the owner in 8 cases. After autopsy, liver, kidneys and stomach content were sampled for toxicological analysis. The presence of carbofuran was determined in three dogs and one cat and the presence of 4,6-dinitro-ortho-cresol in one dog by method of gas-mass chromatography. In these cases of poisoning, on the basis of anamnestic data, clinical picture and autopsy finding it was concluded that poisonings were deliberate. Although the number of confirmed cases of domestic carnivores poisoning during the two-year period is relatively low, it is assumed that the number of undetected and undiagnosed poisoning cases is much higher. Abuse of highly toxic pesticides can have severe consequences for both public health and the overall biodiversity.

Keywords: poisoning, domestic carnivores, banned pesticides, carbofuran, 4,6-dinitro-ortho-cresol

\footnotetext{
${ }^{1 *}$ Corresponding author: biljana@niv.ns.ac.rs
} 


\title{
TROVANJA DOMAĆIH KARNIVORA ZABRANJENIM PESTICIDIMA NA TERITORIJI JUŽNO-BAČKOG OKRUGA
}

\author{
Biljana Đurđevićc ${ }^{*}$, Milena Samojlović ${ }^{1}$, Brankica Kartalović ${ }^{1}$, \\ Radomir Ratajac ${ }^{1}$, Miloš Pelić ${ }^{1}$, Marko Pajić ${ }^{1}$, Vladimir Polaček ${ }^{1}$ \\ ${ }^{1}$ Naučni institut za veterinarstvo "Novi Sad”, Novi Sad, Srbija
}

\section{Kratak sadržaj}

Slučajevi namernih, nezakonitih trovanja životinja se mogu naći u većem broju literaturnih izvora. U novije vreme u Republici Srbiji beleži se porast slučajeva trovanja domaćih i divljih životinja visoko toksičnim pesticidima. U periodu od dve godine (početak 2016. do kraja 2017. godine) u cilju utvrđivanja uzroka uginuća, na Odeljenju za patologiju Naučnog instituta za veterinarstvo „Novi Sad“ obdukovano je ukupno 40 pasa i 2 mačke, sa teritorije Južnobačkog okruga. Na osnovu anamnestičkih podataka, osnovana sumnja na trovanje postavljena je kod 13 pasa i 2 mačke. Ekspertize su obavljane na osnovu zahteva Republičkog veterinarskog inspektora u 5 slučajeva, dok je po zahtevu vlasnika zabeleženo ukupno 8 slučajeva. Nakon izvršene obdukcije, izvršeno je uzorkovanje organa: jetra, bubrezi i sadržaj želuca u cilju toksikoloških analiza. Metodom gasno-masene hromatografije utvrđeno je prisustvo karbofurana u sadržaju želuca i jetri kod tri psa i jedne mačke kao i prisustvo 4,6-dinitro-orto-krezola kod jednog psa. U navedenim slučajevima trovanja je na osnovu anamnestičkih podataka, kliničke slike ili nalaza prilikom patomorfološkog pregleda zaključeno da se radi o slučaju gde je trovanje namerno. Iako je broj potvrđenih slučajeva trovanja domaćih karnivora u toku dvogodišnjeg perioda relativno mali, može se pretpostaviti da je broj neotkrivenih i nedijagnostikovanih slučajeva trovanja životinja znatno veći. Zloupotreba visoko toksičnih pesticida može imati ozbiljne posledice kako na javno zdravlje tako i na celokupan biodiverzitet u regionu.

Ključne reči: trovanje, domaći karnivori, zabranjeni pesticidi, karbofuran, dinitro-orto-krezol. 


\section{INTRODUCTION}

Cases of acute pesticide poisonings of wildlife and domestic animals have been documented worldwide since the middle of the 20th century (Cramp, 1973; Fleischli et al., 2004). The pesticides most frequently involved in animal poisoning are insecticides and rodenticides (Segev et al., 2006; Wang et al., 2007; Yas-Natan et al., 2007; Berny et al., 2010; Anastasio and Sharp, 2011; Caloni et al., 2012; Waddell et al., 2013). Animal poisoning cases by herbicides, molluscicides and fungicides have also been reported but less frequently (Berny et al., 2010; Caloni et al., 2012). There are many data in the literature on unintentional or accidental poisonings with pesticides used in agriculture in target and non-target species. Wild animals are most frequently exposed to accidental poisoning (Kwon et al., 2004; Berny and Gaillet, 2008; MartínezHaro et al., 2008; Slaninova et al., 2009; Wagner et al., 2013; Ogada, 2014). It is estimated that pesticides were illegally used in $68 \%$ of animal poisonings (Berny, 2007).

Restrictions have been made in the European Union on the use of certain chemical preparations used in agriculture, due to their high toxicity (EC 2003, EC 2006). Non-selective and unsafe use of pesticides, as well as the use of poisonous baits for killing non-target species, are some of the most serious problems for public health and biodiversity. Also, there is a growing problem of the conservation of endangered animal species due to the illegal use of pesticides (Ruiz-Suárez et al., 2015). The ban on the use of highly toxic pesticides can reduce their availability and hence the possibility for poisoning of domestic and wild animals. For example, after 1998 the percentage of poisoning of cattle with organochlorine pesticides declined significantly because of the ban on use of these pesticides (Guitart et al., 2010; Caloni et al., 2012). However, intentional or accidental cases of poisoning of animals with banned pesticides are still present in a large percentage worldwide (Tennakoon et al., 2009; Berny et al., 2010; de Siqueira et al., 2015; Ruiz-Suárez et al., 2015). An increased percentage of cases of deliberate, illegal poisoning of domestic and wild animals has been recorded in Republic of Serbia. Although the literature data on the incidence of pesticide poisoning in domestic animals in our country is very scarce, it is known that this number is significantly higher than statistical data show (Aleksic et al., 2014). Killing, causing of injuries, torture or any other form of animal abuse is a criminal act and is regulated by the Criminal law of the Republic of Serbia, Article 269 (Sl. glasnik RS", No. $85 / 2005,88 / 2005$ - ispr., 107/2005 - ispr., 72/2009 i 111/2009). The aim of this article is to describe cases of poisoning of dogs and one cat by forbiden highly 
toxic pesticides (carbofuran and 4,6-dinitro-ortho-cresol) on the territory of the South Bačka District, in the period from the beginning of 2016 to the end of 2017.

\section{MATERIAL AND METHODS}

From January 2016 till the end of 2017, due to a reasonable suspicion of poisoning and to determine the cause of death, autopsies of 13 dogs and 2 cats were performed at the Department of Pathology at the Scientific Veterinary Institute Novi Sad. Autopsies were performed according to the standard protocol of Scientific Veterinary Institute "Novi Sad". Data about breed, age, gender, estimated time of death, body condition and in some cases anamnestic data from the owner about the possible circumstances that led to the death, were collected. In only 3 cases, a suspected bait was found in the immediate proximity of the body, which was also subjected to toxicological analysis. Macroscopic changes in the organs were photo-documented, and samples of stomach contents as well as parenchymal organs (liver, kidney) were collected for toxicological investigations. Quick, easy, cheap, effective, rugged, safe (QuEChERS) sample preparation was used for toxicological analysis and it was adapted from the Association of Analytical Communities (AOAC) Official method 2007.01 for extraction and clean up.

\section{Reagents and Chemicals}

All chemicals and reagents used were of analytical grade with high purity.

\section{Standard Solutions}

Standard solutions were prepared using a carbofuran and 4,6-dinitroortho-cresol standard, manufacturer by Dr. Ehrenstorfer Lot number 10910, Germany and Lot number 41217.

\section{Sample Preparation}

According to Kartalović et al. (2016) adapted method of sample preparation for pesticides (OCP), polychlorinated biphenyl's (PCB) and polyciclic aromatic hydrocrbons (PAHs) was used. This modified method was based on the extraction with acetonitrile (ACN, Sigma-Aldrich) in the presence of anhydrous magnesium sulfate (MgSO4; Merck, Darmstadt, Germany) and anhydrous sodium acetate (CH3COONa; Merck, Darmstadt, Germany). Sample (3 g) was measured and transferred into centrifuge tube, $3 \mathrm{ml}$ of water and $3 \mathrm{ml}$ of Acetonitrile were added. After intensive stirring on a vortex, $3 \mathrm{~g}$ of anhydrous magnesium sulfate and $1 \mathrm{~g}$ of anhydrous sodium acetate were added. Exother- 
mic reaction occurred within $1 \mathrm{~min}$ after the intense stirring on vortex. The sample was then centrifuged until $5 \mathrm{~min}$ at $3000 \mathrm{rpm}$. One milliliter of upper acetonitrile extract is transferred into the $5 \mathrm{ml}$ tube, which contained $150 \mathrm{mg}$ of anhydrous magnesium sulfate, $100 \mathrm{mg}$ of Primary and Secondary Amine (PSA), Merck manufacturer (Darmstadt, Germany), and $50 \mathrm{mg}$ of C18, Merck manufacturer (Darmstadt, Germany), (Anastassiades et al., 2003). The tube content was centrifuged for $5 \mathrm{~min}$ at $3000 \mathrm{rpm}$. After centrifuging, purified and clear extract was obtained. Then, $0.5 \mathrm{ml}$ of the extract was evaporated in nitrogen and reconstituted with hexane. A sample prepared in this way was ready for the analysis on GCMS (Agilent 7890B/5977A, USA).

\section{GCMS Analysis}

Carbofuran and 4,6-dinitro-ortho-cresol identification were based on comparison of the retention times of the peaks and target ions, with those obtained from standard (standards supplied by instrument manufacturer).

Quantification was based on matrix calibrations curves prepared from the standard solution of carbofuran and 4,6 - dinitro-ortho-cresol. The coefficients of determination (r2) for the carbofuran and 4,6-dinitro-ortho-cresol standard calibration plots were more than 0.99 .

\section{Instrumentation}

Agilent 7890B/5977A MSD, gas - mass chromatography was used for analysis. The GC operating conditions were as follow: fused silica column $\left[30 \mathrm{~m}^{\star} 0.25 \mu \mathrm{m}\right.$ film of HP-5M (thickness)]; injection temperature was set at 280 ${ }^{\circ} \mathrm{C}$ using splitless mode and volume injected was $4 \mu \mathrm{L}$. The column temperature was programmed as following: hold at $50^{\circ} \mathrm{C}$ for $0.4 \mathrm{~min} ; 50-195^{\circ} \mathrm{C}$ at 25 ${ }^{\circ} \mathrm{C} / \mathrm{min}$, hold $1.5 \mathrm{~min} ; 195-265$ at $8{ }^{\circ} \mathrm{C} / \mathrm{min}$ and maintained at $315^{\circ} \mathrm{C}$ for 1.25 minutes on $20{ }^{\circ} \mathrm{C} / \mathrm{min}$, MSD temperature was $280^{\circ} \mathrm{C}$. Verification of peaks was carried out based on retention times and target ions, compared to those of external carbofuran and 4,6-dinitro-ortho-cresol. Procedural blank and solvent blanks were analyzed and quantified, but no carbofuran and 4,6-dinitroortho-cresol were found in these blanks.

\section{RESULTS}

From January 2016 till the end of December 2017, in total 40 autopsies of dogs and 2 cats were performed at Department of Pathology at Scientific Veterinary Institute „Novi Sad“ to determine the cause of death. Reasonable suspicion of poisoning in 13 dogs and 2 cats was made based on anamnestic 
data, the appearance of nervous system symptoms as well as the finding of a suspected substance in the proximity of the bodies. The chemical-toxicological analysis of the sampled material was performed in only 7 cases. The expertises were performed on the request of the Republic veterinary inspector in 5 cases, and on the request of the owner in 8 cases.

The finding of toxic pesticides was confirmed in four dogs and one cat by method of gas-mass chromatography. The presence of carbofuran was confirmed in three dogs (two pulin and šarplaninac breed) and one domestic cat, while the presence of 4,6-dinitro-ortho-cresol in gastric content and parenchymal organs was confirmed in one dog (Hungarian viszla breed). In all the cases with carbofuran poisoning, death occurred within 15-30 minutes after the onset of the first clinical symptoms. Clinical signs included convulsions, rotation in circles, appearance of foam in the mouth. There were no anamnestic data about dog poisoned with 4,6-dinitro-ortho-cresol. Two dogs were poisoned in public areas, and other two dogs and the cat in house yards. All poisoned animals had owners. In all these cases of poisoning based on anamnestic data, clinical picture and autopsy findings, it has been concluded that poisonings were done deliberately.

\section{Autopsy findings}

All bodies of dogs and cat that died due to the ingestion of toxic bait were in good body condition. The gross pathology finding of the dog poisoned with 4,6-dinitro-ortho-cresol was greatly unspecific. Hair around the muzzle was colored in yellow. The dominant macroscopic finding in the stomach was the presence of particles of round shape and intense yellow color, mixed with stomach content. Mucus of the stomach was extremely wrinkled and hyperemic (Figure 1).

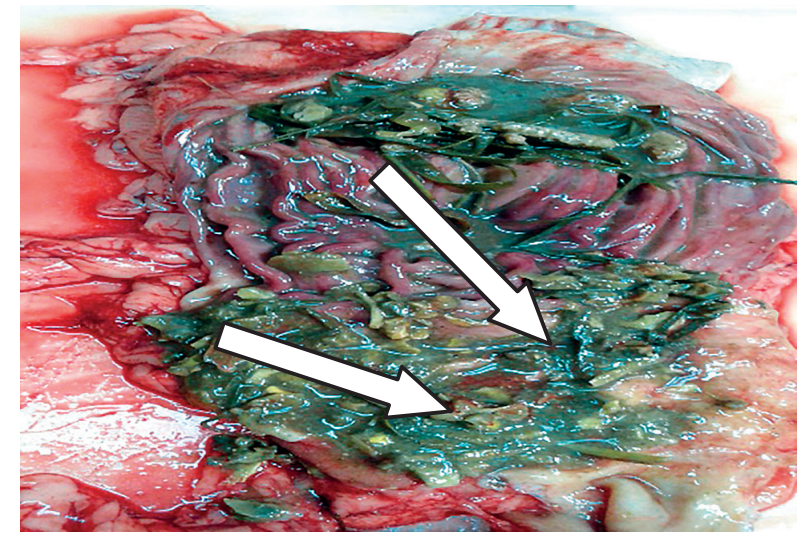

Figure 1: Stomach of the dog. Intense yellow particles are seen in the lumen (arrow). 
In 3 dogs and a cat poisoned with carbofuran, the main macroscopic lesions were in the form of bowel congestion (4/4), presence of haemorrhagic exudate in the abdominal cavity (3/4), and foamy-haemorrhagic content in the lumen of the trachea $(4 / 4)$. In the lumen of the stomach, the presence of partially digested poisonous bait of intense pink color was determined (Figure 2).
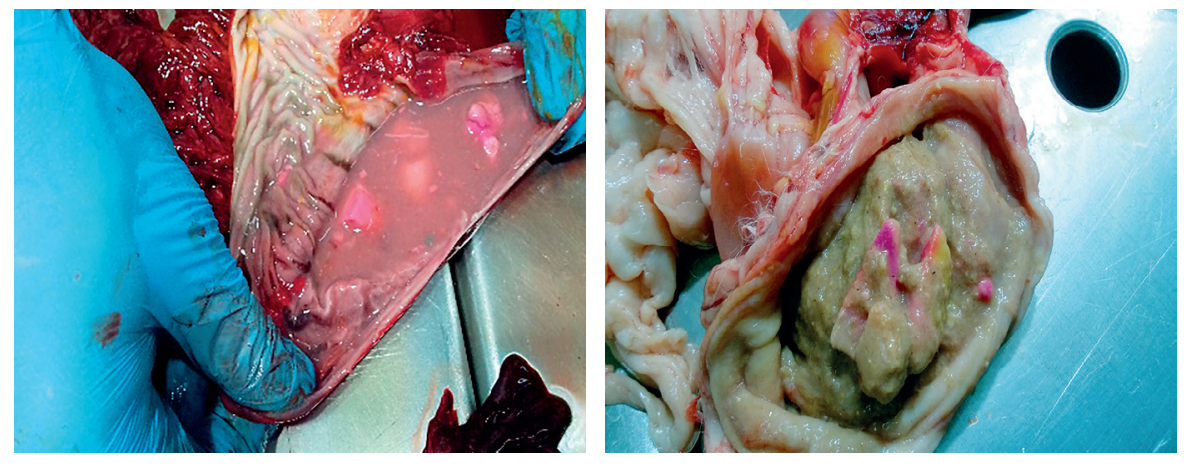

Figure 2. a) Stomach content of the cat. Partially digested poisonous carbofuran bait of intense pink color; b) Stomach content of the dog with poisonous bait inside.

\section{Method for validation of carbofuran and 4,6-dinitro-ortho-cresol}

Validation plan included determination of precision, reproducibility, accuracy, linearity, LOQ, LOD and uncertainty (Kartalović et al., 2016). The method precision was evaluated by repeatability using the meat fortified with carbofuran concentrations injected in triplicate $\left(50.0 \mathrm{mg} \mathrm{kg}^{-1}, \mathrm{n}=20\right)$. Accuracy was calculated by recovery. Linearity of detector was tested in range of 5 to500 $\mathrm{mg} \mathrm{kg}{ }^{-1}$, and was satisfactory in all range. Limit of detection (LOD-standard deviation equal to 3 ) and limit of quantification (LOQ - standard deviation equal to 10) were calculated using the excel program. LOD values ranged $1.6 \mathrm{mg} \mathrm{kg}^{-1}$, and the LOQ was $5 \mathrm{mg} \mathrm{kg}^{-1}$ for carbofuran and 4,6-dinitro-orthocresol. Method preparation and method determination for carbofuran and 4,6 dinitro-ortho-cresol is the same like for pesticides and PCB and because of that in calculating measurement uncertainty the contributions PT (FAPASPesticide Residues in Olive Oil, July - September 2014 Round 0598), the contribution of reproducibility and contribution of bias are taken into account. Calculation of faithfulness for expanded measurement uncertainty for pesticides and polychlorinated biphenyl's in the observed matrix was $38.7 \%$, what satisfies the conditions that are recommended by SANCO 2014 (Kartalović et al., 2016). 
Table 1 . The average values of precision, reproducibility, accuracy, linearity, LOQ and LOD for carbofuran and 4,6-dinitro-ortho-cresol

\begin{tabular}{|l|c|c|c|c|c|c|}
\hline Contaminent & $\begin{array}{c}\text { Preci- } \\
\text { sion (\%) }\end{array}$ & $\begin{array}{c}\text { Reproduc- } \\
\text { ibility (\%) }\end{array}$ & $\begin{array}{c}\text { Accuracy } \\
(\%)\end{array}$ & $\begin{array}{c}\text { Linear- } \\
\text { ity }\left(\mathrm{r}^{2}\right)^{\mathrm{a}}\end{array}$ & $\begin{array}{c}\text { LOQ } \\
\left(\mu \mathrm{kg}^{-1}\right)\end{array}$ & $\begin{array}{c}\text { LOD } \\
\left(\mu \mathrm{gg}^{-1}\right)\end{array}$ \\
\hline Carbofuran & 11.3 & 6.33 & 95,02 & 0,99853 & 1,21 & 0,36 \\
\hline $\begin{array}{l}\text { Dinitro-4,6- } \\
\text { ortho-cresol }\end{array}$ & 13.2 & 7.24 & 94.21 & 0.99893 & 1.91 & 0.56 \\
\hline
\end{tabular}

$\left({ }^{a} \mathrm{r}^{2}-\right.$ correlation coefficient)

\section{DISCUSSION}

Three cases of acute poisoning of dogs and a cat with carbofuran, as well as one case of poisoning of the dog with 4,6-dinitro-ortho-cresol in the territory of South Bačka district during two year period (2016-2017) are described in this paper. In recent years there has been an increase in the number of cases of deliberate poisoning of domestic and wild animals with prohibited pesticides in the Republic of Serbia (Mihaljev et al., 2013; Aleksic et al., 2014). When it comes to poisonings of domestic animals in Europe, reports from many countries show that the highest percentage of poisonings is recorded in dogs, then in cats, horses and small ruminants (Berny et al., 2010). The most commonly used poisons included carbamate insecticides such as aldicarb and carbofuran (Tennakoon et al., 2009; Berny et al., 2010; Novotný et al., 2011; Ruiz-Suárez et al., 2015).

Carbofuran is one of the most toxic carbamate pesticides. The active substance is 2,3-dihydro-2,2-dimethyl-7-benzofuran-1-methylcarbamate. Carbofuran acts as a reverse inhibitor of acetylcholine esterase enzyme. It is easily consumed by target species because its formulation is suitable for mixing with pet food, meat, fish (De Siqueira et al., 2015). Animal owners mostly find their pets dead or with a severe clinical picture typical for a cholinergic crisis involving dyspnoea, diarrhea and convulsions (Khan, 2012). Such conditions require urgent veterinary intervention. Brain and skeletal muscles (target tissues) are mostly affected by the toxic effect of carbamate insecticides, while cardiovascular, respiratory, reproductive and immune systems can also be affected. Atropine sulphate is used for the control of muscarinic receptors as the 
only specific physiological antidote for carbamate toxins (Tse et al., 2013). In most animals that died due to carbamate pesticide poisoning, the macroscopic and histopathological findings were mostly unspecific, and the changes were usually in the form of systemic congestion and hemorrhage in most organs (De Siqueira et al., 2015), which match our findings. Histopathologic changes in the form of neuron death in several parts of the brain (hippocampus, cortex, thalamus, amygdala) are described in acute carbamate poisoning in rats. In severe forms of poisoning necroses of skeletal muscles are also described (Gupta, 2007). Since 2007, the European Union has prohibited trade of products containing carbofuran (EC, 2007). Although the ban on the use of this pesticide is expected to reduce the number of animal poisonings, researches worldwide suggest that poisonings are still common (De Siqueira et al., 2015; Bille et al., 2016; Caloni et al., 2016;). Carbofuran is forbidden for use in Serbia since 2014, due to its high toxicity and negative ecotoxicological effects.

4,6-Dinitro-ortho-cresol (DNOC) is a cresol derivative, yellowish crystalline solid. It is used in agriculture as larvicide, insecticide and ovicide. DNOC is classified in class Ib, 'highly hazardous', in the WHO Recommended Classification of Pesticides by Hazards (WHO, 1999). Although the use of DNOC as a pesticide is prohibited in many countries, significant quantities of unused pesticides exist, especially in developing countries (World Health Organization, 2000). Dinitro-ortho-cresol can be absorbed through the skin as well as by ingestion or inhalation of aerosols. Workers in the agricultural and chemical industries are most often exposed. In acute exposure to dinitro-ortho-cresol by ingestion, inhalation or through skin, there are signs of poisoning in the form of difficult breathing, increased thirst, accelerated breathing, nausea, anorexia, and intense yellow pigmentation occurs. Liver, kidney and central nervous system damage has been reported in acute poisoning of people. Chronic exposure to DNOC results in the occurrence of the same symptoms. According to Dere et al., DNOC causes cellular damage at vital organs such as liver, kidneys, and lungs, thus inducing changes in the physiological and metabolic activities (Dere et al., 2007). Acute oral exposures to DNOC resulting in toxicity and death have been reported in rats, mice, cats and pigs at relatively similar doses. 


\section{CONCLUSIONS}

Intentional and accidental poisonings of animals with high toxic pesticides pose a threat to human health as well as to general public health and safety. Pesticides such as carbofuran and 4,6-dinitro-ortho-cresol are forbidden for usage in the European Union as well as in Serbia, but poisonings continue to occur both in domestic animals and wildlife. Toxico-epidemiological data from most European countries show that pet poisoning is a very important and frequent veterinary problem. The results obtained in this paper show that poisonings of companion animals by banned pesticides such as carbofuran and 4,6-dinitro-ortho-cresol are still present in our country. Considering that this study covers a short period of time ( 2 years) and population of carnivores from a small geographical area (South Backa District), more detailed countrywide studies need to be carried out to obtain an insight into the incidence of poisoning of domestic animals in our country.

\section{ACKNOWLEDGEMENTS}

This investigation was supported by a grants from the Ministry of Education, Science and Technological Development of the Republic of Serbia, Project No. 31084 and No. 31011.

\section{REFERENCES}

1. Aleksic J., Batricevic A., Jovasevic D., Aleksic Z.: Animal poisoning - veterinary-medical and criminal-legal aspects. Veterinarski Glasnik, 68, 3-4, 251-263, 2014.

2. Anastasio J.D., Sharp C.R.: Acute aldicarb toxicity in dogs: 15 cases (20012009). Journal of Veterinary Emergency and Critical Care, 21, 3, 253-260, 2011.

3. Anastassiades M., Lehotay S.J., Stajnbaher D., Schenck F.J.: Fast and easy multiresidue method employing acetonitrile extraction/partitioning and "dispersive solid-phase extraction" for the determination of pesticide residues in produce. The Journal of AOAC International, 86, 2, 412-31, 2003.

4. Berny P.: Pesticides and the intoxication of wild animals. Journal of Veterinary Pharmacology and Therapeutics, 30, 2, 93-100, 2007.

5. Berny P., Caloni F., Croubels S., Sachana M., Vandenbroucke V., Davanzo F., Guitart R.: Animal poisoning in Europe. Part 2: Companion animals. The Veterinary Journal, 183, 3, 255-259, 2010. 
6. Berny P., Gaillet J.R.: Acute poisoning of red kites (milvus milvus) in France: data from the sagir network. Journal of Wildlife Diseases, 44, 2, 417-426, 2008.

7. Bille L., Toson M., Mulatti P., Dalla Pozza M., Capolongo F., Casarotto C., Ferrè N., et al.: Epidemiology of animal poisoning: An overview on the features and spatio-temporal distribution of the phenomenon in the northeastern Italian regions. Forensic Science International, 266, 440-448, 2016.

8. Caloni F., Berny P., Croubels S., Sachana M., Guitart R.: Epidemiology of animal poisonings in Europe. Veterinary Toxicology, 88-97, 2012.

9. Caloni F., Cortinovis C., Rivolta M., Davanzo F.: Suspected poisoning of domestic animals by pesticides. Science of The Total Environment, 539, 331-336, 2016.

10. Cramp S.: The Effects of Pesticides on British Wildlife. British Veterinary Journal, 129, 4, 315-323, 1973.

11. Dere E., Ozdikicioglu F., Tosunoglu H.: Hepatotoxicity of dinitro-o-cresol in rats (Rattus norvegicus). Acta Veterinaria Belgrade, 57, 5-6, 497-507, 2007.

12. EC. Council Decision of 18 March 2003 concerning the non-inclusion of aldicarb in Annex I to Council Directive 91/414/EEC and the withdrawal of authorisations for plant protection products containing this active substance. Official Journal of the European Union, 22/03/2003; L 076:0021-4, 2003.

13. EC. Commission Decision of 13 June 2007 concerning the non-inclusion of carbofuran in Annex I to Council Directive 91/414/EEC and the withdrawal of authorisations for plant protection products containing that substance. Official Journal of the European Union 16/06/2007; L 156:0030$1,2007$.

14. EC. Commission Regulation No 199/2006 of 19 December 2006 amending Regulation (EC) No 466/2001 setting maximum levels for certain contaminants in foodstuffs as regards dioxins and dioxin-like PCBs. Official Journal of the European Union, 20/12/2006; L 364:0005-24, 2006.

15. Fleischli M.A., Franson J.C., Thomas N.J., Finley D.L., Riley W.: Avian mortality events in the United States caused by anticholinesterase pesticides: a retrospective summary of National Wildlife Health Center records from 1980 to 2000. Archives of Environmental Contamination and Toxico$\log y, 46,4,542-50,2004$.

16. Guitart R., Croubels S., Caloni F., Sachana M., Davanzo F., Vandenbroucke V., Berny P.: Animal poisoning in Europe. Part 1: Farm livestock and poultry. The Veterinary Journal, 183, 3, 249-254, 2010. 
17. Gupta R.C.: Veterinary Toxicology. 1st Edition Basic and Clinical Principles, Academic Press, Kentucky, USA, 2007.

18. Kartalović B., Novakov N.J., Mihaljev Ž., Petrović J., Prica N., Babić J., Ćirković M.A.: Organochlorine pesticides in canned tuna and sardines on the Serbian market. Food Additives and Contaminants: Part B Surveillance, Taylor \& Francis, 9, 4, 299-304, 2016.

19. Khan S.A.: Differential Diagnosis of Common Acute Toxicologic Versus Nontoxicologic Illness. Veterinary Clinics of North America: Small Animal Practice, 42, 2, 389-402, 2012.

20. Kwon Y.-K., Wee S.-H., Kim J.-H.: Pesticide Poisoning Events in Wild Birds in Korea from 1998 to 2002. Journal of Wildlife Diseases, Wildlife Disease Association, 40, 4, 737-740, 2004.

21. Martínez-Haro M., Mateo R., Guitart R., Soler-Rodríguez F., Pérez-López M., María-Mojica P., García-Fernández A.J.: Relationship of the toxicity of pesticide formulations and their commercial restrictions with the frequency of animal poisonings. Ecotoxicology and Environmental Safety, 69, 3, 396-402, 2008.

22. Mihaljev Z., Maric B., Ratajac R., Živkov Baloš M., Jaksic S.: Confirmation of carbofuran poisoning of wildlife. 2nd International Symposium on Hunting, " Modern Aspects of Sustainable Management of Game Populations, Novi Sad, Serbia, 17 - 20. October, 2013, 249-253.

23. Novotný L., Misík J., Honzlová A., Ondráček P., Kuča K., Vávra O., Rachač V., et al.: Incidental poisoning of animals by carbamates in the Czech Republic. Journal of Applied Biomedicine, 9, 3, 157-161, 2011.

24. Ogada D.L.: The power of poison: pesticide poisoning of Africa's wildlife. Annals of the New York Academy of Sciences, 1322, 1, 1-20, 2014.

25. Ruiz-Suárez N., Boada L.D., Henríquez-Hernández L.A., González-Moreo F., Suárez-Pérez A., Camacho M., Zumbado M., et al.: Continued implication of the banned pesticides carbofuran and aldicarb in the poisoning of domestic and wild animals of the Canary Islands (Spain). Science of the Total Environment, 505, 1093-1099, 2015.

26. Segev G., Yas-Natan E., Shlosberg A., Aroch I.: Alpha-chloralose poisoning in dogs and cats: A retrospective study of 33 canine and 13 feline confirmed cases. The Veterinary Journal, 172, 1, 109-113, 2006.

27. Službeni glasnik, R.S.: Krivični zakonik. Beograd: Službeni glasnik Republike Srbije, 85/2005, 88/2005 - ispr., 107/2005 - ispr., 72/2009 i 111/2009.

28. De Siqueira A., Salvagni F.A., Yoshida A.S., Gonçalves-Junior V., Calefi A.S., Fukushima A.R., Spinosa H. de S., et al.: Poisoning of cats and dogs by the carbamate pesticides aldicarb and carbofuran. Research in Veterinary 
Science, 102, 142-149, 2015.

29. Slaninova A., Smutna M., Modra H., Svobodova Z.: A review: oxidative stress in fish induced by pesticides. Neuro Endocrinology Letters, 30, 1, 2-12, 2009.

30. Tennakoon S., Perera B., Haturusinghe L.: Intentional poisoning cases of animals with anticholinesterase pesticide-carbofuran in Sri Lanka. Legal Medicine, 11, S500-S502, 2009.

31. Tse Y.C., Sharp C.R., Evans T.: Mechanical ventilation in a dog with acetylcholinesterase inhibitor toxicosis. Journal of Veterinary Emergency and Critical Care, 23, 4, 442-446, 2013.

32. Waddell L.S., Poppenga R.H., Drobatz K.J.: Anticoagulant rodenticide screening in dogs: 123 cases (1996-2003). Journal of the American Veterinary Medical Association, 242, 4, 516-521, 2013.

33. Wagner N., Reichenbecher W., Teichmann H., Tappeser B., Lötters S.: Questions concerning the potential impact of glyphosate-based herbicides on amphibians. Environmental Toxicology and Chemistry, 32, 8, 16881700, 2013.

34. Wang Y., Kruzik P., Helsberg A., Helsberg I., Rausch W.D.: Pesticide poisoning in domestic animals and livestock in Austria: A 6 years retrospective study. Forensic Science International, 169, 2-3, 157-160, 2007.

35. World Health Organization. DINITRO- ortho -CRESOL, 2000.

36. Yas-Natan E., Segev G., Aroch I.: Clinical, neurological and clinicopathological signs, treatment and outcome of metaldehyde intoxication in 18 dogs. Journal of Small Animal Practice, 48, 8, 438-443, 2007.

Primljeno: 05.04.2018.

Odobreno: 10.06.2018. 